\title{
Unexpected Impact of a Hepatitis C Virus Inhibitor on $17 \beta$-Estradiol Signaling in Breast Cancer
}

\author{
Stefania Bartoloni, Stefano Leone and Filippo Acconcia *(B) \\ Department of Sciences, Section Biomedical Sciences and Technology, University Roma Tre, Viale Guglielmo \\ Marconi, 446, I-00146 Rome, Italy; stefania.bartoloni2@uniroma3.it (S.B.); stefano.leone@uniroma3.it (S.L.) \\ * Correspondence: filippo.acconcia@uniroma3.it; Tel.: +39-06-57336320; Fax: +39-06-57336321
}

Received: 29 April 2020; Accepted: 11 May 2020; Published: 12 May 2020

\begin{abstract}
Estradiol (E2) controls diverse physiological processes, including cell proliferation, through its binding to estrogen receptor $\alpha(E R \alpha)$. E2:ER $\alpha$ signaling depends on both the receptor subcellular localization (e.g., nucleus, plasma membrane) and intracellular ER $\alpha$ abundance. Indeed, the control of ER $\alpha$ levels is necessary for the effects of E2, and E2 itself induces ER $\alpha$ degradation and cell proliferation in parallel. Thus, the modulation of intracellular ER $\alpha$ levels is a critical parameter for E2-induced cell proliferation. Therefore, we used this parameter as a bait to identify compounds that influence ER $\alpha$ levels and E2-dependent proliferation in breast cancer (BC) cells from a library of Food and Drug Administration (FDA)-approved drugs. We found that telaprevir (Tel) reduces ER $\alpha$ levels and inhibits BC cell proliferation. Tel is an inhibitor of the hepatitis $C$ virus (HCV) NS3/4A serine protease, but its effect on E2:ER $\alpha$ signaling has not been investigated. Here, for the first time, we analyzed the effects of Tel on intracellular ER $\alpha$ levels and E2:ER $\alpha$ signaling to cell proliferation in different $E R \alpha$-expressing BC cell lines. Overall, our findings demonstrate that Tel reduces intracellular $\mathrm{ER} \alpha$ levels, deregulates $\mathrm{E} 2 \mathrm{ER} \alpha$ signaling and inhibits E2-induced proliferation in $\mathrm{BC}$ cells and suggest the potential drug repurposing of Tel for the treatment of $\mathrm{BC}$.
\end{abstract}

Keywords: $17 \beta$-estradiol; estrogen receptor $\alpha$; telaprevir; breast cancer

\section{Introduction}

The hormone $17 \beta$-estradiol (E2), the most effective estrogen, regulates a plethora of physiological effects by binding estrogen receptor $\alpha(E R \alpha)[1,2]$. $E R \alpha$, which belongs to the nuclear receptor superfamily, acts as a ligand-activated transcription factor to drive E2-responsive gene expression through multiple mechanisms (i.e., nuclear and extranuclear signaling) [2-9].

Moreover, E2 action is a function of not only the subcellular localization but also the intracellular levels of $\mathrm{ER} \alpha[3,10]$. The $\mathrm{ER} \alpha$ protein exhibits a high turnover rate, and intracellular receptor levels change over time. Change in the ER $\alpha$ content is necessary to drive E2-dependent cell functions and regulate cell responsiveness to this hormone. Indeed, E2 itself controls the ER $\alpha$ content, simultaneously triggering receptor degradation and inducing cell proliferation $[3,10]$. Thus, the modulation of intracellular ER $\alpha$ levels is a critical parameter for E2 signaling $[3,9,11]$. Hence, factors that deregulate the physiological control of intracellular ER $\alpha$ levels can potentially inhibit E2 signaling and downstream effects, such as cell proliferation. Accordingly, synthetic ER $\alpha$ ligands (e.g., fulvestrant [ICI182,780-ICI] and tamoxifen) alter intracellular ER $\alpha$ levels and inhibit E2-dependent breast cancer (BC) cell proliferation [10,12]. Molecules that do not bind ER $\alpha$ (e.g., carfilzomib and emetine) also influence the ER $\alpha$ abundance and prevent E2-induced BC cell proliferation $[13,14]$. In addition, the inhibition or depletion of proteins belonging to pathways unrelated to E2:ER $\alpha$ signaling (e.g., metabolic and endocytic proteins) blocks BC cell proliferation, changing the cellular ER $\alpha$ content [11,15-19]. Thus, the modulation of intracellular $\mathrm{ER} \alpha$ levels and E2-dependent BC cell proliferation are interrelated. 
Based on this evidence, our laboratory recently demonstrated that modulation of the ER $\alpha$ content can be used as a parameter to identify compounds that can alter ER $\alpha$ levels and prevent E2-dependent BC cell proliferation [3,13-15,20]. Thus, a library of Food and Drug Administration (FDA)-approved drugs was applied to ER $\alpha$-expressing ductal carcinoma cells (MCF-7), and seven compounds were found to influence the ER $\alpha$ content and cell proliferation [14]. The effects of one such compound, telaprevir (Tel), on these processes have never been investigated. Tel is a reversible inhibitor of the hepatitis $\mathrm{C}$ virus (HCV) NS3/4A serine protease approved by the FDA for the treatment of patients with genotype $1 \mathrm{HCV}$ infection, in combination with pegylated interferon and ribavirin [21,22].

Here, we aimed to validate and characterize the impact of Tel on E2:ER $\alpha$ signaling to BC cell proliferation.

\section{Results}

\subsection{Telaprevir Affects Intracellular ER $\alpha$ Levels}

To identify new compounds that can influence intracellular ER $\alpha$ levels and E2-dependent proliferation in BC cells, a screen of FDA-approved drugs was performed in our laboratory [14]. The results of the screen suggested that telaprevir (Tel) (Figure 1a) reduces intracellular ER $\alpha$ levels and prevents basal and E2-induced proliferation in MCF-7 cells. Therefore, initial experiments were undertaken to validate the effect of Tel on the ER $\alpha$ content in different ER $\alpha$-expressing BC cell lines [MCF-7, T47D-1, ZR-75-1, BT-474, MDA-MB-361 and Y537S-ER $\alpha$ mutant-expressing MCF-7 (Y537S) cells]. For this purpose, cells were treated with increasing doses of Tel $(10$ to $40 \mu \mathrm{M})$ for $24 \mathrm{~h}$. As shown in Figure $1 \mathrm{~b}$, Tel reduced intracellular ER $\alpha$ levels in a dose-dependent manner in each cell line tested. In particular, $20 \mu \mathrm{M}$ Tel significantly reduced intracellular ER $\alpha$ levels in most of the cell lines, although the lowest concentration of Tel at which a reduction in ER $\alpha$ was observed differed between the tested cell lines.

In addition, the Tel-mediated reduction in ER $\alpha$ levels was compared to the effects of three different selective estrogen receptor downregulators (SERDs): fulvestrant (ICI 182,780-ICI), AZD9496 (AZD) and brilanestrant (GDC-0810-GDC) [23,24]. For this purpose, MCF-7, T47D-1, BT-474 and Y537S cells were treated with Tel $(20 \mu \mathrm{M})$, ICI $(100 \mathrm{nM})$, AZD $(100 \mathrm{nM})$ and GDC $(100 \mathrm{nM})$ for $24 \mathrm{~h}$. The results (Figure 1c) indicate that Tel and ICI reduced ER $\alpha$ levels in each cell line tested, as expected. Interestingly, the ability of Tel to reduce the receptor content in T47D-1 and BT-474 cells was similar to that of ICI. Moreover, AZD and GDC induced a decrease in ER $\alpha$ content in MCF-7, T47D-1 and Y537S cells, although the effects of these antiestrogens were not observed in BT-474 cells. Notably, Tel reduced the ER $\alpha$ content in T47D- 1 and BT-474 cells to a greater extent than AZD or GDC.

Overall, these findings demonstrate that Tel influences the control of intracellular ER $\alpha$ levels and that the ability of Tel to reduce the ER $\alpha$ content of BC cells is similar to that of SERDs.

\subsection{Telaprevir-Dependent Mechanism for the Control of ER $\alpha$ Levels}

The intracellular levels of ER $\alpha$ in pools of both preformed and neosynthesized ER $\alpha$ are controlled [25]. Since Tel influences ER $\alpha$ abundance (Figure 1), the effect of this compound on the pool of ER $\alpha$ already produced in the cell (i.e., preformed ER $\alpha$ ) was investigated in MCF-7, T47D-1,BT-474 cells as well as in Y537S cells (Supplementary Figure S1b). Thus, cells were pretreated with the protein synthesis inhibitor cycloheximide (CHX, $1 \mu \mathrm{g} / \mathrm{mL})$ for $6 \mathrm{~h}$ before $24 \mathrm{~h}$ of Tel $(20 \mu \mathrm{M})$ treatment. The results showed that Tel and CHX reduced ER $\alpha$ levels, as expected. Interestingly, Tel did not influence the CHX-dependent reduction in intracellular ER $\alpha$ levels in each cell line tested (Figure 2a). These data suggest that Tel does not affect preformed ER $\alpha$. Next, experiments were performed to assess the ability of Tel to alter ER $\alpha$ mRNA levels and hence the levels of newly produced ER $\alpha$ by mRNA translation (i.e., neosynthesized ER $\alpha$ ) [10,25]. As shown in Figure 2b, Tel reduced ER $\alpha$ mRNA levels in MCF-7, T47D- 1 and BT-474 cells. Taken together, these findings suggest that Tel controls the ER $\alpha$ content at the transcriptional level, triggering a decrease in ER $\alpha$ mRNA expression in MCF-7, T47D-1 and BT-474 cells. 
(a)

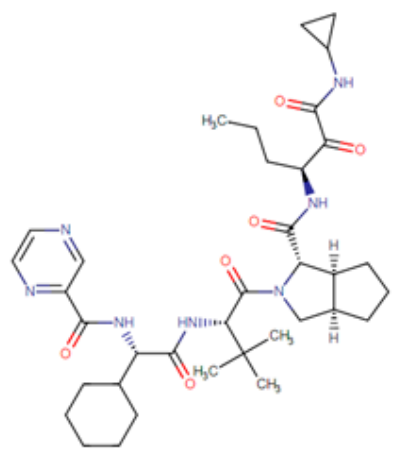

(b)
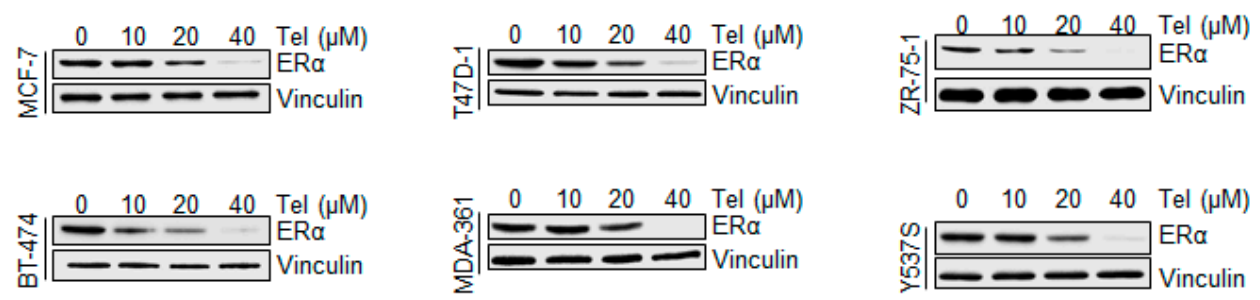

(c)
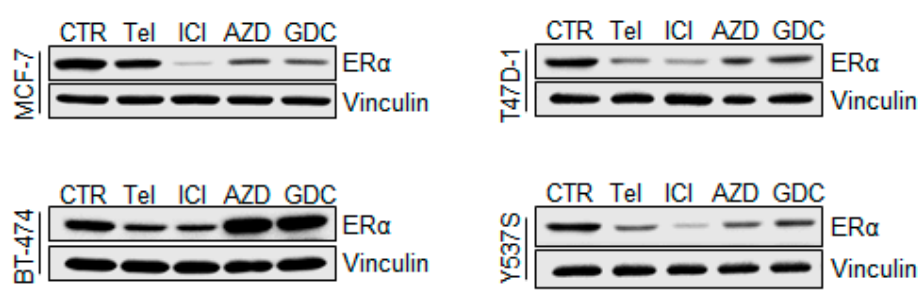

Figure 1. The effect of telaprevir on ER $\alpha$ intracellular levels. (a) Schematic of the telaprevir chemical formula as depicted in DrugBank (n.: DB05521). (b) Western blotting analysis of ER $\alpha$ cellular levels in MCF-7, T47D-1, ZR-75-1, BT-474, MDA-MB-361 and Y537S cells treated with different doses of telaprevir (Tel) for $24 \mathrm{~h}$. The loading control was done by evaluating vinculin expression in the same filter. (c) Western blotting analysis of ER $\alpha$ expression levels in MCF-7, T47D-1, BT-474 and Y537S cells treated with Tel $(20 \mu \mathrm{M})$, fulvestrant (ICI $100 \mathrm{nM})$, AZD9496 (AZD $100 \mathrm{nM})$ and GDC-0810 (GDC $100 \mathrm{nM}$ ) for $24 \mathrm{~h}$. The loading control was done by evaluating vinculin expression in the same filter. Panels $a$ and $b$ show representative blots from at least three independent experiments.

However, these results did not exclude the possibility that Tel can bind ER $\alpha$. Therefore, the capability of Tel to bind ER $\alpha$ was analyzed through an in vitro fluorescence polarization-based competitive binding assay performed at room temperature and under steady-state conditions (i.e., measurement of the binding was performed at $2 \mathrm{~h}$ ). Figure 2c illustrates that E2 displaced the fluorescent ligand mimicking $\mathrm{E} 2$ from $\mathrm{ER} \alpha$ and bound the receptor with an $\mathrm{IC}_{50}$ (i.e., $\mathrm{K}_{\mathrm{d}}$ ) of approximately $3 \mathrm{nM}$. Notably, the measured $\mathrm{K}_{\mathrm{d}}$ of $\mathrm{E} 2$ towards $\mathrm{ER} \alpha$ was in the range of that measured under different conditions and with different techniques $[3,26]$. Conversely, Tel did not induce displacement of the fluorescent ligand, indicating that Tel could not bind ER $\alpha$ in vitro. 
(a)

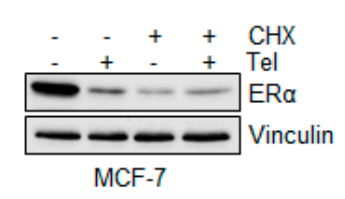

(b)

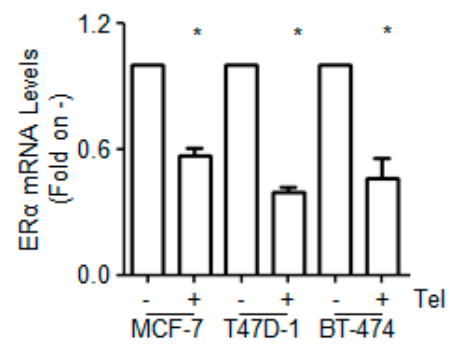

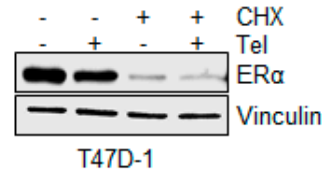

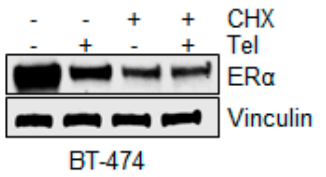

(c)

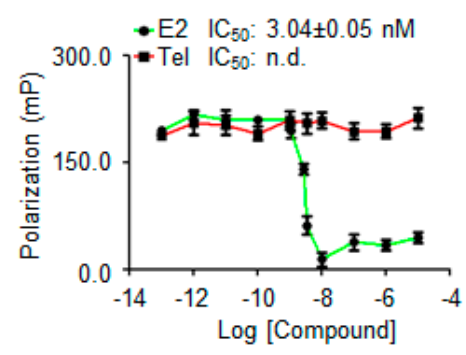

Figure 2. The mechanism of telaprevir-dependent ER $\alpha$ reduction. (a) Western blotting analysis of pre-formed ER $\alpha$ levels in MCF-7, T47D-1 and BT-474 cells pre-treated with cycloheximide (CHX $1 \mu \mathrm{g} / \mathrm{mL})$ for $6 \mathrm{~h}$ and then treated with telaprevir $(\mathrm{Tel} 20 \mu \mathrm{M})$ for $24 \mathrm{~h}$. The loading control was done by evaluating vinculin expression in the same filter. Panels show representative blots from at least three independent experiments. (b) In vitro ER $\alpha$ competitive binding assays for telaprevir (Tel-red) and 17 $\beta$-estradiol (E2-green) performed at different doses of the compounds and using a florescent E2 as tracer. Inhibitor concentration $50\left(\mathrm{IC}_{50}-\mathrm{nM}\right)$ is indicated in the panel for each compound. The experiment was performed twice in quintuplicate. (c) RT-qPCR analysis of ER $\alpha$ mRNA levels in MCF-7, T47D-1 and BT-474 cells treated with Tel $(20 \mu \mathrm{M})$ for $24 \mathrm{~h}$. ER $\alpha$ mRNA expression was normalized to the GAPDH mRNA expression. * indicates significant differences with respect to the control sample (-). Data are the mean \pm standard deviations with a $p$ value $<0.01$. All experiments were performed in triplicate.

\subsection{Effect of Telaprevir on ER $\alpha$ Transcriptional Activity}

$E R \alpha$ degradation is intrinsically connected with the transcriptional activity of the receptor $[27,28]$. Thus, the impact of Tel on ER $\alpha$ transcriptional activity was analyzed. Initial experiments were performed to evaluate the influence of Tel on ER $\alpha$ target gene expression through RT-qPCR-based E2-sensitive gene array analysis. Initially, the quality of the assay was tested by comparing MCF-7 cells and mutant ER $\alpha$-expressing MCF-7 (Y537S) cells. As Y537S-ER $\alpha$ is constitutively activated in the absence of E2 [29], Y537S cells were used as a model to measure E2-induced gene expression. The pie diagrams in Figure 3a show that $66.3 \%$ (yellow) of the array genes were significantly modulated in Y537S cells compared to MCF-7 cells and that 83\% (green) of these genes were upregulated in Y537S cells. Among them were trefoil factor 1 (TFF1-pS2), cathepsin D (Cat D) and caveolin 1 (Cav 1), as expected [29]. Thus, the assay effectively gauged E2:ER $\alpha$ signaling. Next, the effect of Tel was analyzed in MCF-7 cells treated for $24 \mathrm{~h}$ with the antiviral. As shown in Figure 3b, Tel modulated 34.8\% (yellow) of the genes in the array. Interestingly, $91 \%$ (red) of the modulated genes were downregulated by Tel, suggesting that the compound prevents ER $\alpha$ transcriptional activity.

To support this observation, the effect of Tel was next analyzed by measuring the real-time kinetics of ER $\alpha$ transcriptional activity in MCF-7 cells stably transfected with an E2-responsive ERE-nanoluciferase (NLuc)-PEST reporter gene construct (MCF-7 ERE-NLuc) [30]. The results reported in Figure 3c show that E2 (10 nM) induced a time-dependent increase in ERE-NLuc activity, as expected [30]. Notably, Tel blocked basal and E2-induced ERE-NLuc activity in a time-dependent manner (Figure 3c). Dose response analyses were also performed, which showed an effect after $24 \mathrm{~h}$ of treatment (Figure $3 \mathrm{c}^{\prime}$ ). Therefore, this evidence indicates that Tel inhibits the transcriptional activity of the receptor. 
(a)
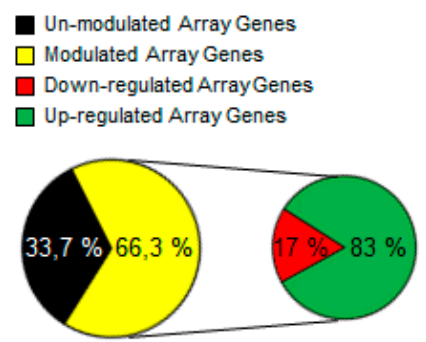

(c)

Modulated genes in Y537S vs MCF-7

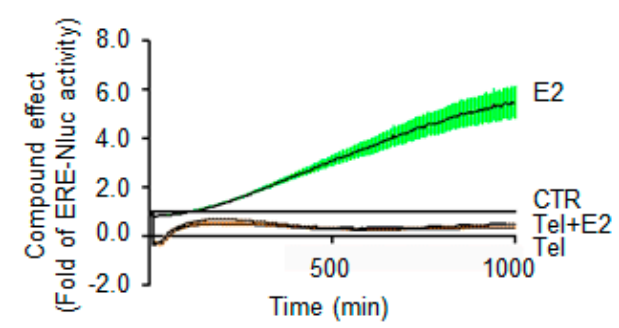

(d)

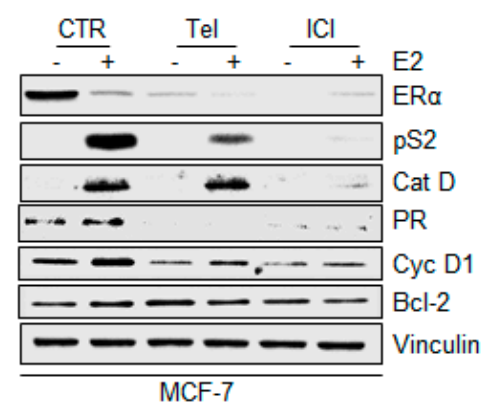

(f)

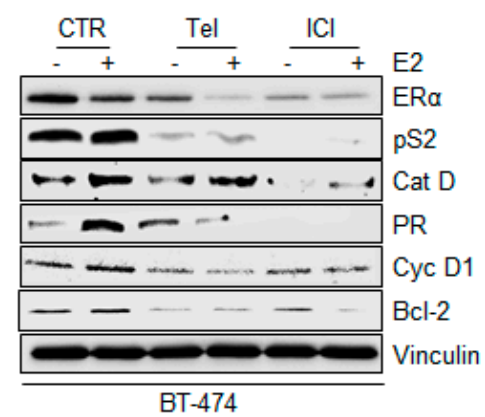

(b)

Un-modulated Array Genes

$\square$ Modulated Array Genes

$\square$ Down-regulated Array Genes

$\square$ Up-regulated Array Genes

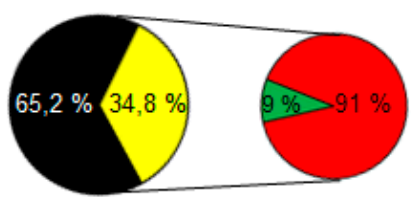

Modulated genes by Tel in MCF-7

(c')

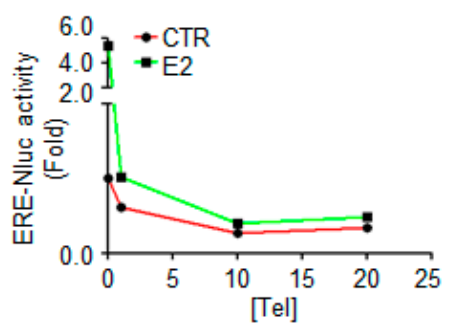

(e)

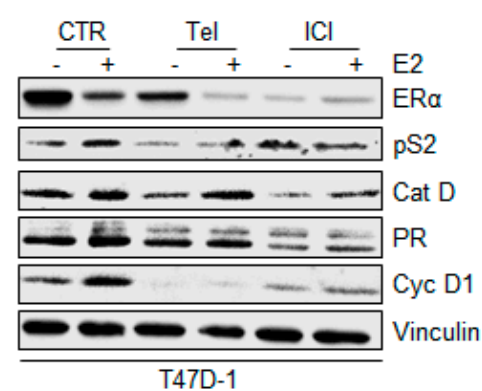

(g)

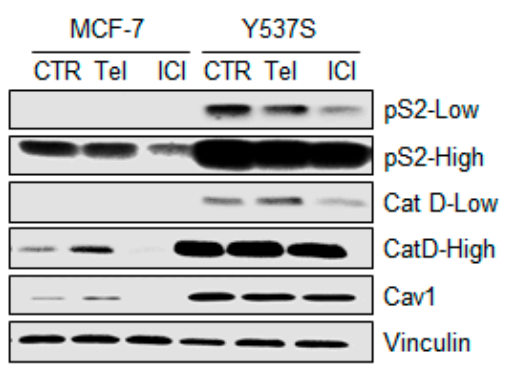

Figure 3. The effect of Telaprevir on E2:ER $\alpha$ nuclear signaling. (a) Pie diagrams representing the percentage of the array genes modulated in Y537S compared to MCF-7 cells and (b) pie diagrams depicting the percentage of the array genes modulated by $24 \mathrm{~h}$ of telaprevir $(\mathrm{Tel} 20 \mu \mathrm{M})$ treatment in MCF-7 cells. (c) Time-dependent profile of ERE-NLuc activity detected in MCF-7 ERE-NLuc cells treated with Tel $(20 \mu \mathrm{M})$ and $17 \beta$-estradiol (E2 $10 \mathrm{nM})$. ( $\left.\mathbf{c}^{\prime}\right)$ Profile of ERE-NLuc activity detected in MCF-7 ERE-NLuc cells treated with different doses of Tel in the absence and in the presence of E2 $(10 \mathrm{nM})$ and detected after $24 \mathrm{~h}$ of compound administration. (d-f) Western blotting analysis of ER $\alpha$, presenilin 2 (pS2), cathepsin D (Cat D), progesterone receptor (PR), cyclin D1 (Cyc D1) and Bcl-2 expression in MCF-7, T47D-1 and BT-474 cells pre-treated with Tel $(20 \mu \mathrm{M})$ and fulvestrant (ICI $100 \mathrm{nM})$ for $24 \mathrm{~h}$ before $24 \mathrm{~h}$ of $\mathrm{E} 2(10 \mathrm{nM})$ treatment. The loading control was done by evaluating vinculin expression on the same filter. (g) Western blotting analysis of pS2, Cat D and caveolin 1 (Cav 1) protein levels in Y537S cells compared to MCF-7 cells. Cells were treated with Tel (20 $\mu \mathrm{M})$ and ICI (100 nM) for $24 \mathrm{~h}$. The loading control was done by evaluating vinculin expression on the same filter. Panels $\mathrm{d}, \mathrm{e}, \mathrm{f}$ and $g$ show representative blots from at least three independent experiments. 
Consequently, the ability of Tel to alter the expression of estrogen-responsive element (ERE)-containing genes (e.g., presenilin2 [pS2], cathepsin D [Cat D] and progesterone receptor [PR]) and non-ERE-containing genes (e.g., Bcl-2 and cyclin D1 [Cyc D1]) was evaluated in MCF-7, T47D-1 and BT-474 cells. Cells were treated with Tel $(20 \mu \mathrm{M})$ and ICI $(100 \mathrm{nM}$, as an internal control) in the absence and presence of E2 $(10 \mathrm{nM})$. Notably, E2-dependent ER $\alpha$ degradation in each cell line was enhanced in the presence of Tel, while Tel administration reduced the receptor content (Figure $3 \mathrm{~d}-\mathrm{f}$ ). These results support the notion that Tel does not bind ER $\alpha$. In addition, Tel prevented E2-induced accumulation of pS2, PR and Cyc D1 in MCF-7, T47D-1 and BT-474 cells (Figure 3d-f) and blocked E2-dependent Bcl-2 overexpression in MCF-7 and BT-474 cells (Figure 3d,f). However, the ability of E2 to trigger Cat D expression was not inhibited by Tel (Figure 3d-f). Moreover, the results indicated that Tel increased the basal protein level of Bcl-2 in MCF-7 cells (Figure 3d). These last observations suggest that a mechanism unrelated to ER $\alpha$ is involved in the regulation of Cat D and Bcl-2 expression.

Finally, the protein levels of three genes (e.g., pS2, Cat, Cav 1), whose expression was upregulated in Y537S cells [29], were analyzed to confirm the impact of Tel in preventing ER $\alpha$ transcriptional activity. Consistent with the array gene analysis (Figure 3a), pS2, Cat D and Cav 1 expression was upregulated in Y537S cells compared to MCF-7 cells (Figure 3g). Furthermore, Tel reduced pS2 levels in Y537S cells but did not influence Cat D or Cav 1 expression in this cell line (Figure 3g), thus supporting the possibility of an alternative mechanism for the control of their expression.

Overall, these results demonstrate that Tel blocks ER $\alpha$ transcriptional activity and suggest that a Tel-dependent reduction in intracellular ER $\alpha$ levels affects, at least in part, the expression of E2:ER $\alpha$ target genes.

\subsection{Effect of Telaprevir on E2-Dependent Breast Cancer Cell Proliferation}

E2-dependent activation of ER $\alpha$ transcriptional activity promotes DNA synthesis, cell cycle progression and cell proliferation in BC cells $[8,31]$. Therefore, the impact of Tel on E2-dependent DNA synthesis and cell cycle progression was studied through a bromodeoxyuridine (BrdU) incorporation assay and cell cycle analysis, respectively, in MCF-7, T47D-1 and BT-474 cells.

As expected, E2 triggered BrdU incorporation in each cell line tested (Figure $4 \mathrm{a}-\mathrm{c}$ ). Tel prevented basal and E2-induced BrdU incorporation in T47D-1 and BT-474 cells (Figure 4b,c), while in MCF-7 cells, Tel reduced basal BrdU incorporation but could not prevent the E2-induced increase in DNA synthesis (Figure 4a). Furthermore, cell cycle analysis (Figure $4 a^{\prime}-c^{\prime}$ ) indicated that E2 treatment increased the number of MCF-7, T47D-1 and BT-474 cells in the S and G2 phases of the cell cycle. In contrast, Tel led to the accumulation of cells in the G1 phase of the cell cycle in each cell line. Moreover, Tel prevented E2-dependent accumulation of T47D-1 and BT-474 cells in the S and G2 phases of the cell cycle but did not affect the accumulation of MCF-7 cells in the S and G2 phases. Therefore, these findings suggest that Tel could interfere with the proliferative ability of the tested cell lines.

In turn, real-time growth curve analysis was conducted in MCF-7, T47D-1 and BT-474 cells as previously reported [30]. As shown by the results (Figure 5a-c), E2 promoted the proliferation of MCF-7, T47D-1 and BT-474 cells, while Tel treatment significantly reduced basal and E2-induced proliferation in each cell line. Notably, Tel in the presence of E2 reduced cell proliferation to a higher extent than Tel treatment alone (Figure $5 \mathrm{a}-\mathrm{c}$ ).

Taken together, these data indicate that Tel blocks basal and E2-induced BC cell proliferation. 
(a)

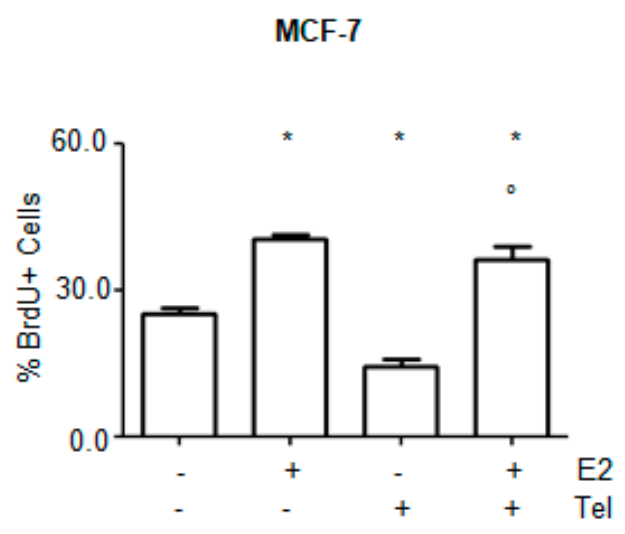

(b)

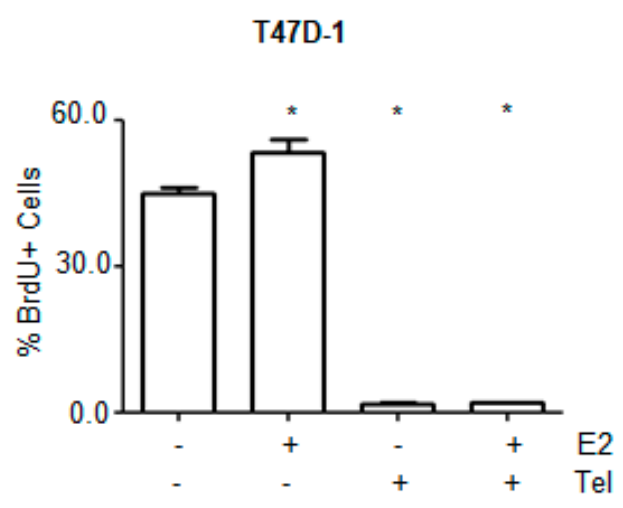

(c)

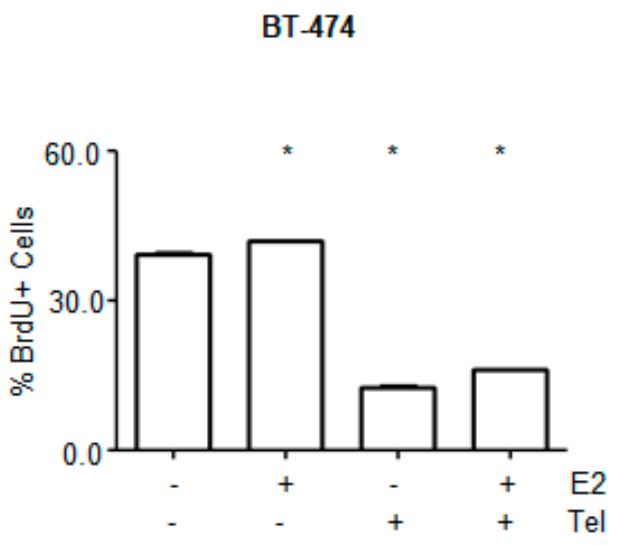

(a')
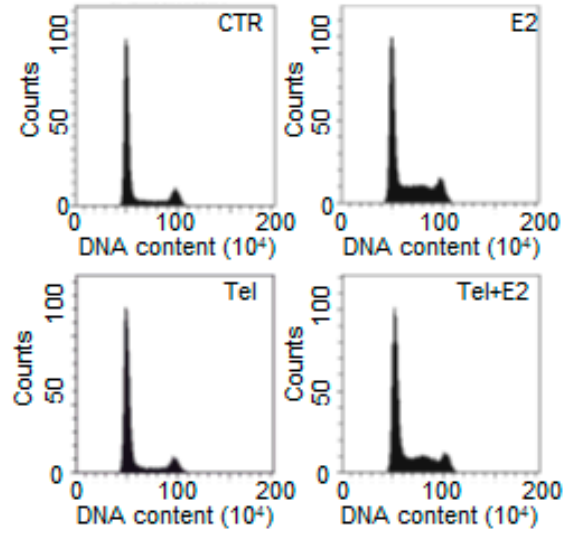

(b')
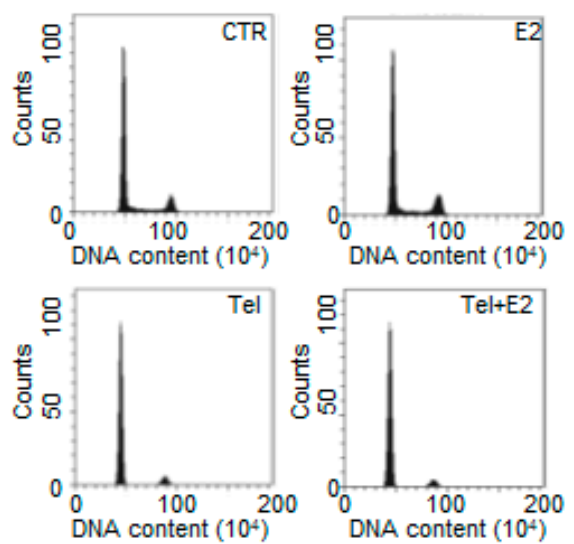

(c')
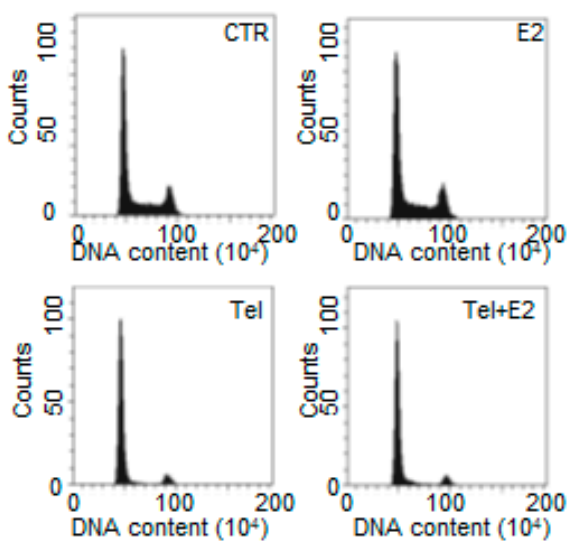

Figure 4. The effect of telaprevir on E2-dependent DNA synthesis and cell cycle progression. $(\mathbf{a}-\mathbf{c})$ bromodeoxyuridine (BrdU) incorporation assay and $\left(\mathbf{a}^{\prime}-\mathbf{c}^{\prime}\right)$ cell cycle analysis in MCF-7, T47D-1 and BT-474 cells. Cells were pre-treated with telaprevir (Tel $10 \mu \mathrm{M}$ in MCF-7 cells, $20 \mu \mathrm{M}$ in T47D-1 and BT-474 cells) for $24 \mathrm{~h}$ before $24 \mathrm{~h}$ of $17 \beta$-estradiol (E2 $10 \mathrm{nM})$ treatment. * indicates significant differences with respect to control sample $(-,-),{ }^{\circ}$ indicated significant differences with respect to the corresponding E2 CTR sample $(+,-)$. Data are the mean \pm standard deviations with a $p$ value $<0.01$. 
(a)

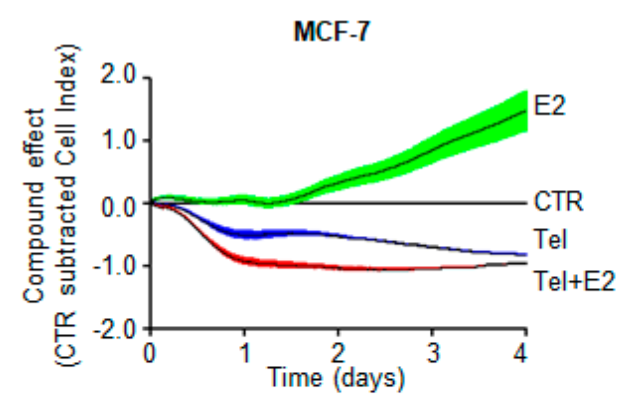

(b)

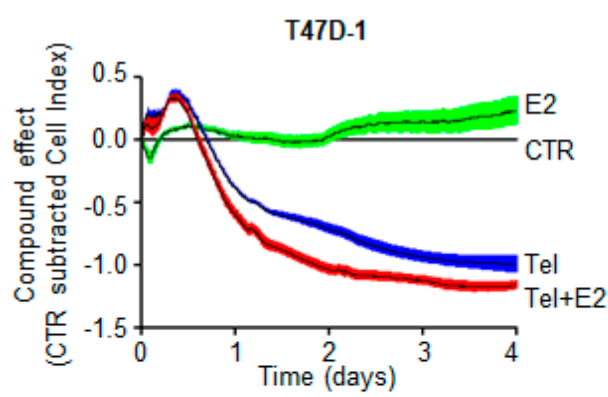

(c)

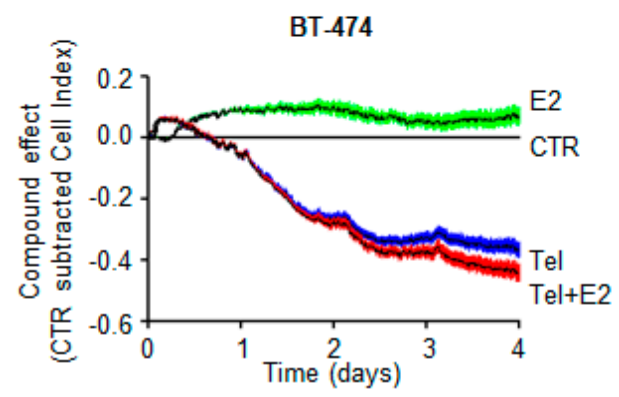

Figure 5. The effect of telaprevir on breast cancer cell proliferation. Real-time growth curves in (a) MCF-7, (b) T47D-1 and (c) BT-474 treated with telaprevir (Tel $20 \mu \mathrm{M}$ ) in the absence (blue line) and in the presence (red line) of $17 \beta$-estradiol (E2 $10 \mathrm{nM}$ ) and with $\mathrm{E} 2$ alone (10 $\mathrm{nM}$ green line) for the indicated time points. The graphs show Tel and E2 effect on the cell index (i.e., cell number), which is detected with the $x$ Celligence DP device and calculated at each time point with respect to control sample (CTR grey line). Each sample was measured in quadruplicate. For details, please see material and methods section.

\section{Discussion}

The primary aim of this work was to characterize the effect of the antiviral Tel on the regulation of intracellular ER $\alpha$ levels and on E2:ER $\alpha$ signaling in BC cell proliferation. E2 is a mitogen for $\mathrm{BC}$, and $\mathrm{ER} \alpha$ is the main driver of $\mathrm{E} 2$-dependent proliferation in approximately $70 \%$ of all cases of $\mathrm{BC}[8,9,12,31]$. Moreover, the cellular effects of E2 are correlated with hormone-dependent regulation of the intracellular ER $\alpha$ content. Indeed, simultaneously E2 reduces ER $\alpha$ levels and induces cell proliferation. Therefore, the control of intracellular $\mathrm{ER} \alpha$ abundance is required for proper cell responsiveness to E2 [3,8-10,12,31,32].

Interestingly, accumulating data suggest that factors that deregulate the physiological control of intracellular ER $\alpha$ levels can inhibit cell proliferation elicited by E2. In turn, synthetic ER $\alpha$ ligands (e.g., fulvestrant and tamoxifen) and molecules that do not bind the receptor (e.g., chloroquine, emetine and carfilzomib) alter intracellular ER $\alpha$ levels and inhibit BC cell proliferation [3,12]. Furthermore, the inhibition or depletion of proteins belonging to pathways unrelated to E2:ER $\alpha$ signaling (e.g., metabolic and endocytic proteins) also prevent BC cell proliferation by changing the ER $\alpha$ content $[11,15-19,33]$. Therefore, the modulation of intracellular ER $\alpha$ levels is a sensitive parameter for E2-dependent cell proliferation. In this respect, it was recently proposed that the modulation of intracellular ER $\alpha$ levels could be used as a bait to identify compounds that can influence the ER $\alpha$ content, and in turn, cell proliferation [3]. These compounds that directly or indirectly affect the balance between the modulation of ER $\alpha$ levels and E2-dependent proliferation were grouped in a supercategory and defined as selective modulators of ER $\alpha$ levels and degradation (e.m.eral.d.s) [3]. Based on this proof of concept study, we screened a library of FDA-approved drugs in ER $\alpha$-expressing ductal carcinoma cells (MCF-7) [14] and found the unsuspected role of Tel as a compound that reduces $\mathrm{ER} \alpha$ levels and prevents basal and E2-induced cell proliferation. Tel is an inhibitor of the hepatitis C 
virus (HCV) NS3/4A serine protease [21], but its effect on E2:ER $\alpha$ signaling in cell proliferation has never been investigated.

Here, we demonstrate for the first time that Tel reduces $\mathrm{ER} \alpha$ levels in six different $\mathrm{ER} \alpha$-expressing BC cell lines, acting as models of primary (i.e., MCF-7, T47D-1, and ZR-75-1 cells) and metastatic (i.e., BT-474, MDA-MB-361 and Y537S-ER $\alpha$ mutant-expressing MCF-7 [Y537S] cells) BC [3]. Treatment with $20 \mu \mathrm{M}$ Tel results in a significant decrease in the ER $\alpha$ content of MCF-7, T47D-1, ZR-75-1, BT-474 and Y537S cells but not MDA-MB-362 cells, but this effect was observed when the compound was applied at higher doses in this latter cell line. Although we observed the effect of Tel at a micromolar concentration, it is important to note that this relatively high dose is in the range of the plasma concentration of Tel reached after administration of Tel at therapeutic doses [34]. Moreover, the effect of Tel on ER $\alpha$ protein levels was observed under both growth (Figure 1b) and starvation (Supplementary Figure S1a) conditions. Interestingly, Tel reduces ER $\alpha$ levels at lower concentrations under starvation conditions than under growth conditions. This phenomenon is probably due to the different growth rates of the cells in different cell culture media. Notably, this observation suggests not only that Tel activity is related to the cell cycle but also that Tel is more effective when used in combination with drugs that induce cell cycle arrest in G1 phase. Accordingly, we observed that Tel blocks the cells in G1 phase of the cell cycle (see also below). In addition, the fact that the effect of Tel on ER $\alpha$ degradation is generally comparable to that of the antiestrogens (i.e., competitive ER $\alpha$ antagonists that induce ER $\alpha$ degradation via the $26 S$ proteasome $[23,24]$ ) fulvestrant (ICI182,780-ICI), AZD9496 (AZD) and brilanestrant (GDC-0810 GDC) in MCF-7, T47D-1, BT-474 and Y537S cells (Figure 1c) indicates that this drug could work in a manner similar to that of SERDs in BC cells.

However, the Tel-mediated reduction in ER $\alpha$ occurs at the posttranscriptional level, as Tel induces a decrease in ER $\alpha$ mRNA levels without binding the receptor (Figure 2) or affecting $26 \mathrm{~S}$ proteasome activity (data not shown). We did not analyze the mechanism underlying the effect of Tel on ER $\alpha$ mRNA levels in this study; however, expression of the ER $\alpha$ gene (ESR1) is regulated by genetic and epigenetic mechanisms that in turn could be influenced by the antiviral compound $[3,9]$. ESR 1 is under the control of at least seven promoters, and different transcription factors control its differential expression in target tissues [3,9]. Interestingly, several lines of evidence suggest that ER $\alpha$ expression strongly correlates with the expression of two transcription factors, FOXA1 and GATA-3, in BC [35,36]. Notably, both the FOXA1 and GATA-3 genes were included in the E2-sensitive gene array, and we found that Tel reduces the levels of these genes (Figure $3 b$ ). Moreover, histone methylation regulates $\mathrm{ER} \alpha \mathrm{mRNA}$ synthesis, and the inhibition or siRNA-mediated depletion of histone methyltransferases (e.g., DOT1L and WHSC1) downregulated ER $\alpha$ expression in BC cells [37,38]. Therefore, a possible explanation for the Tel-mediated reduction in ER $\alpha$ is that Tel impairs the activity of transcription factors and/or epigenetic regulators involved in the control of ER $\alpha$ expression. However, it is important to note that Tel affects ER $\alpha$ levels in all the tested cell lines, suggesting a certain degree of specificity for Tel activity in BC cells.

Additionally, the presented data indicate that the Tel-mediated reduction in intracellular ER $\alpha$ levels partially turns off ER $\alpha$ target gene expression by preventing transcriptional activity of the receptor. RT-qPCR-based gene array analysis of ER $\alpha$ signaling revealed that E2-target gene downregulation prevails after Tel treatment, as $91 \%$ of the genes included in the array that are modulated by Tel were downregulated in MCF-7 cells (Figure 3b). We initially evaluated the quality of the test used to measure ER $\alpha$ nuclear signaling. As the Y537S mutation confers estrogen-independent activity to the receptor, we evaluated E2-induced target gene expression in genome-edited Y537S-ER $\alpha$-expressing cells (Y537S) [29] in comparison with parental MCF-7 cells. We concluded that the assay effectively measures $\mathrm{E} 2: \mathrm{ER} \alpha$ signaling because expression of the array genes was significantly upregulated in Y537S cells compared to MCF-7 cells (Figure 3a). Among the modulated genes were trefoil factor 1 (TFF1 or pS2), cathepsin D (Cat d) and caveolin 1 (Cav 1), which are known to be overexpressed in Y537S cells [29]. We also confirmed the overexpression of these genes in Y537S cells compared to MCF-7 cells by Western blotting (Figure 3g). Hence, we assumed that results of the array gene analysis 
clearly reflect the impact of the tested antiviral on ER $\alpha$ nuclear signaling. Accordingly, real-time evaluation of ER $\alpha$ transcriptional activity in MCF-7 ERE-NLuc cells [30] showed that Tel blocks basal and E2-induced ER $\alpha$ transcriptional activity in a time- and dose-dependent manner (Figure 3c, $c^{\prime}$ ). Furthermore, the effect of Tel on ER $\alpha$ transcriptional activity also influences the ability of E2 to induce expression of ERE- and non-ERE-containing genes. In turn, Tel prevents E2-dependent pS2, Cat D and PR accumulation in MCF-7, T47D-1 and BT-474 cells and Bcl-2 upregulation in MCF-7 and BT-474 cells (Figure d-f). Notably, Tel also partially affects the activity of the Y537S-ER $\alpha$ mutant. The Y537S mutation, one of the most recurrent point mutations in ESR1, is linked to acquired resistance to endocrine therapy in metastatic BC [29,39-41]. Interestingly, Tel reduces pS2 expression in Y537S cells, even though Cav 1 expression is unresponsive to Tel and antiestrogen (i.e., ICI) treatment in this cell line (Figure 3g).

Nevertheless, E2 still induces Cat D expression in the presence of Tel in each cell line. In addition, Tel itself enhances basal Bcl-2 protein levels in MCF-7 cells, presumably as a compensatory response of the cells for survival [42]. The expression of Cat D and Bcl-2 may rely on a mechanism unrelated to ER $\alpha$ involving another type of estrogen receptor. Recently, G-protein coupled estrogen receptor 1 (GPER1, also known as GPR30) was discovered as a new E2 receptor, and its role in mediating cell responses to E2 has been studied both in vitro and in vivo. GPR1 is expressed in several BC cell lines and contributes to $\mathrm{E} 2$ and antiestrogen nuclear and extranuclear signaling in BC [43,44]. Thus, we cannot exclude that GPR1 is involved in Cat D and Bcl-2 expression in the presence of Tel, as evidence suggests the involvement of this receptor in transcriptional activation of E2-target genes (e.g., Cat D, Bcl-2 and Cyc D1) [43].

Tel activity blocks the mitogenic effects evoked by E2 in BC cells. In turn, Tel perturbs basal and E2-dependent DNA synthesis, cell cycle progression and proliferation in three different BC cell lines (i.e., MCF-7, T47D-1 and BT-474 cells) (Figures 4 and 5). E2-dependent promotion of the G1 to $\mathrm{S}$ phase transition plays a critical role in $\mathrm{BC}$ pathogenesis. The action of $\mathrm{E} 2$ in cell cycle progression involves ER $\alpha$-mediated cyclin D1 overexpression, cyclin-dependent kinase (CDK) activation and retinoblastoma $(\mathrm{Rb})$ protein phosphorylation $[1,31]$. Therefore, targeting the ability of E2 to induce cell cycle progression is an important issue for BC treatment. In turn, antiestrogens (e.g., tamoxifen and fulvestrant) and selective inhibitors of CDK4/6 (e.g., Palbociclib) counteract E2 activity, triggering cell cycle arrest in G1 phase of the cell cycle in BC cells [12,31]. We report that Tel induces the accumulation of BC cells in G1 phase of the cell cycle also in response to E2 stimulation. This observation is consistent with the effect of the abovementioned compounds already used in clinics for the treatment of BC. Nonetheless, we found that Tel does not prevent E2-induced DNA synthesis or cell cycle progression in MCF-7 cells (Figure 4a), in contrast to the observed effects in T47D-1 and BT-474 cells. In this respect, it is tempting to speculate that the residual effect of E2 can be ascribed to the different levels of $E R \alpha$ in the different cell lines [45] after Tel administration. However, real-time growth curve analysis revealed that Tel inhibits both basal and E2-dependent proliferation of MCF-7, T47D-1 and BT-474 cells. Surprisingly, the antiproliferative effect of Tel is enhanced in the presence of E2. Thus, E2 may have a toxic effect on cells exposed to Tel. This situation could be due to the influence of Tel on pathways that protect cells against excessive proliferative and transcriptional stimuli induced by E2 [46,47]. From this perspective, ovarian function suppression and consequent premature menopause [48] would no longer be necessary for premenopausal women with $\mathrm{ER} \alpha$-positive BC who would receive Tel treatment. However, the selectivity of Tel for BC instead of different types of cancer as well as Tel-mediated toxicity in normal breast cells (e.g., MCF10a cells) requires further evaluation.

Another important issue to discuss concerns the molecular target of Tel in $\mathrm{BC}$ cells. Tel is a direct antiviral agent designed to target the HCV NS3/4A serine protease. Inhibition of the NS3/4A serine protease by Tel blocks cleavage of the genome-encoded polyprotein into mature viral proteins, preventing the generation of the machinery required for $\mathrm{HCV}$ replication [21]. Moreover, Tel activity also prevents NS3/4A-dependent proteolysis of cellular proteins (e.g., TRIF, MAVS and CARIF) involved in the host innate immune response, which leads to the inhibition of type-I interferon (INF) induction and 
consequent HCV escape from the immune system [49-52]. Given the essential role of type-I INFs as regulators of cancer immunosurveillance in $\mathrm{BC}$, it might be interesting to evaluate whether Tel influences components of the IFN system in BC cells [53-55]. However, it has been reported that $\mathrm{Tel}$ is a substrate and inhibitor of P-glycoprotein (P-gp, ABCB1), which is an ATP-binding cassette transporter involved in ADME of a variety of drugs and implicated in multidrug resistance [56-58]. Therefore, the inhibitory potential of Tel against P-gp could enable clinically relevant drug interactions, which must be considered. In addition, to define a possible candidate molecular target for Tel in BC cells, we hypothesized that this antiviral affects eukaryotic protease activities since Tel is an inhibitor of a viral proteases. Therefore, we analyzed the impact of Tel on the three protease activities (i.e., chymotrypsin-like, caspase-like and trypsin-like) in the proteasome, the main protease-based system in the cell, in vitro. However, Tel has no effect (data not shown) on this cellular proteolytic system. Thus, the challenge of identifying cellular target(s) of Tel in BC cells remains an open question that needs to be addressed through different approaches (e.g., transcriptomic, proteomic and in silico approaches).

In conclusion, here, we demonstrate that Tel reduces intracellular ER $\alpha$ levels, deregulates E2:ER $\alpha$ signaling and inhibits E2-induced proliferation in BC cells. Remarkably, the findings reported in this work also support the use of selective modulation of intracellular ER $\alpha$ levels as a target to identify new compounds that affect E2:ER $\alpha$ signaling in $\mathrm{BC}$ cell proliferation and serve as the basis for future evaluation of Tel repurposing in the treatment of primary and metastatic BC.

\section{Materials and Methods}

\subsection{Cell Culture and Reagents}

$17 \beta$-Estradiol (E2), Dulbecco's modified Eagle's medium (with and without phenol red) and fetal calf serum were purchased from Sigma-Aldrich (St. Louis, MO). A Bradford protein assay kit and anti-mouse and anti-rabbit secondary antibodies were obtained from Bio-Rad (Hercules, CA, USA). Antibodies against ER $\alpha$ (HC-20, rabbit), cyclin D1 (H-295, rabbit), Bcl-2 (C2, mouse), progesterone receptor (C20, rabbit), cathepsin D (H75, rabbit), and pS2 (FL-84, rabbit) were obtained from Santa Cruz Biotechnology (Santa Cruz, CA). Anti-vinculin antibody was purchased from Sigma-Aldrich (St. Louis, MO, USA). Chemiluminescence reagent for Western blotting was obtained from Bio-Rad Laboratories (Hercules, CA, USA). Fulvestrant (i.e., faslodex or ICI 182,780), AZD9496 and brilanestrant (GDC) were purchased from Tocris (Bristol, UK). Telaprevir (VX-950) was purchased from Selleck Chemicals (Houston, TX, USA). All the other products were obtained from Sigma-Aldrich. Analyticalor reagent-grade products were used without further purification.

\subsection{Western Blot Analysis}

Cells were grown in DMEM with phenol red plus 10\% fetal calf serum for $24 \mathrm{~h}$ and then treated with telaprevir (Tel), fulvestrant (ICI), AZD9496 (AZD) or brilanestrant (GDC) at the indicated doses for the indicated periods. Before E2 stimulation, cells were grown in DMEM without phenol red plus $1 \%$ charcoal-stripped fetal calf serum for $24 \mathrm{~h}$; Tel, ICI and cycloheximide (CHX) were added before E2 administration. After treatment, cells were lysed in Yoss Yarden (YY) buffer (50 mM Hepes (pH 7.5), $10 \%$ glycerol, $150 \mathrm{mM} \mathrm{NaCl}, 1 \%$ Triton X-100, 1 mM EDTA and $1 \mathrm{mM} \mathrm{EGTA)} \mathrm{plus} \mathrm{protease}$ and phosphatase inhibitors. Western blot analysis was performed by loading 20-30 $\mu \mathrm{g}$ of protein onto SDS-gels. The gels were run, and the proteins were transferred to nitrocellulose membranes with a Turbo-Blot semidry transfer apparatus from Bio-Rad (Hercules, CA, USA). Immunoblotting was carried out by incubating the membranes with $5 \%$ milk or bovine serum albumin (60 min), followed by incubation overnight (o.n.) with the indicated antibodies. Secondary antibody incubation was continued for an additional $60 \mathrm{~min}$. Bands were detected using a Chemidoc apparatus from Bio-Rad (Hercules, CA, USA). 


\subsection{Growth Curves}

The xCELLigence DP system (ACEA Biosciences, Inc., San Diego, CA, USA) Multi-E-Plate station was used to measure time-dependent responses to E2 and Tel by real-time cell analysis. Each experimental condition was tested in quadruplicate. A detailed description of the instrument and related software has been previously published [59]. The instrument measures the electric impedance of cells on the well surface. The software transforms the measured value of the electric impedance into a nondimensional parameter called the cell index (CI). An increased electric impedance (hence an increased CI) is proportional to an increase in the number of cells. The CI normalized for each well at time 0 was used to follow cell proliferation according to the software manufacturer's instructions. MCF-7, T47D-1, and BT-474 cells were seeded in growth medium in E-plates 96. After o.n. monitoring of impedance once every $15 \mathrm{~min}$, the medium was changed, and cells were grown in medium containing $1 \%$ charcoal-stripped fetal calf serum and Tel in the presence or absence of E2 until the end of the experiment. Cellular impedances were then recorded once every $15 \mathrm{~min}$ for a total time of $72 \mathrm{~h}$.

\subsection{Real-Time Measurement of ER $\alpha$ Transcriptional Activity}

MCF-7 cells were stably transfected with a plasmid containing an ERE-nanoluciferase (NLuc)-PEST reporter gene, and real-time measurement of NLuc-PEST expression (i.e., ER $\alpha$ transcriptional activity) was performed as described [30].

\subsection{In Vitro Binding Assay}

A fluorescence polarization (FP) assay was used to measure the binding affinities of telaprevir (Tel) and $17 \beta$-estradiol (E2) for recombinant ER $\alpha$ in vitro. The FP assay was performed using a PolarScreen ${ }^{\mathrm{TM}} \mathrm{ER} \alpha$ Competitor Assay Kit, Green (Thermo Scientific). Measurements were performed according to the manufacturer's instructions by administering different doses of the test compounds in a final assay reaction that contained ER $\alpha(75 \mathrm{nM})$ and Fluormone ES2 $(4 \mathrm{nM})$ in ER $\alpha$ binding buffer. Each sample was measured in quintuplicate in black 384-well plates, and the experiment was repeated twice. The assay was conducted for $2 \mathrm{~h}$ (i.e., to reach steady-state conditions) in the dark at room temperature before the results were read on a Tecan Spark ELISA reader capable of detecting fluorescence polarization.

\subsection{RNA Isolation and qPCR Analysis}

The sequences for gene-specific forward and reverse primers were designed using the OligoPerfect Designer software program (Invitrogen, Carlsbad, CA, USA). The following primers were used: human ER $\alpha$ : 5'-GTGCCTGGCTAGAGATCCTG-3' (forward) and 5'-AGAGACTTCAGGGTGCTGGA-3' (reverse) and human GAPDH: 5'-CGAGATCCCTCCAAAATCAA-3' (forward) and 5'-TGTGGTCAT GAGTCCTTCCA-3' (reverse). Total RNA was extracted from cells using TRIzol reagent (Invitrogen, Carlsbad, Ca, USA) according to the manufacturer's instructions. To determine gene expression levels, cDNA synthesis and qPCR were performed using the GoTaq 2-step RT-qPCR system (Promega, Madison, MA, USA) in an ABI Prism 7900 HT Sequence Detection System (Applied Biosystems, Foster City, CA, USA) according to the manufacturer's instructions. Experiments were performed in triplicate. RT-qPCR-based gene array analysis of ER $\alpha$ target gene expression was determined using the PrimePCR Estrogen receptor signaling (SAB Target List) H96 panel (Bio-Rad Laboratories, Hercules, CA, USA) according to the manufacturer's instructions. Gene expression was normalized to GAPDH mRNA levels.

Gene arrays for estrogen signaling were used according to the manufacturer's instructions (Bio-Rad).

\subsection{Bromodeoxyuridine Incorporation Assay}

Bromodeoxyuridine (BrdU) was added to the medium in the last $30 \mathrm{~min}$ of growth, and the cells were then fixed and permeabilized. Histones were dissociated with $2 \mathrm{M} \mathrm{HCl}$ as previously described 
(Darzynkiewicz and Juan, 2001). BrdU-positive cells were detected with anti-BrdU primary antibody diluted 1:100 (DAKO Cytomatation; Santa Clara, CA, USA) and Alexa488-conjugated anti-mouse antibody diluted 1:100 (Thermo Fisher Scientific; Waltham, MA, USA). Both antibodies were incubated with the cells for $1 \mathrm{~h}$ at room temperature in the dark. BrdU fluorescence was measured using a CytoFLEX flow cytometer, and cell cycle analysis was performed with CytExpert v1.2 software (Beckman Coulter, Brea, CA, USA). All samples were counterstained with propidium iodide (PI) for DNA/BrdU biparametric analysis.

\subsection{Cell Cycle Analysis}

After treatments, cells were harvested with trypsin and counted to obtain $10^{6}$ cells per condition. Then, the cells were centrifuged at $1500 \mathrm{rpm}$ for $5 \mathrm{~min}$ at $4{ }^{\circ} \mathrm{C}$, fixed with $1 \mathrm{~mL}$ of ice-cold $70 \%$ ethanol, and subsequently stained with PI buffer $(500 \mu \mathrm{g} / \mathrm{mL}$ PI and $320 \mu \mathrm{g} / \mathrm{mL}$ RNase A in $0.1 \%$ Triton X in phosphate-buffered saline). DNA fluorescence was measured using a CytoFLEX flow cytometer (Beckman Coulter, Brea, CA, USA), and cell cycle analysis was performed with CytExpert v1.2 software (Beckman Coulter, Brea, CA, USA).

\subsection{Statistical Analysis}

Statistical analysis was performed using ANOVA (one-way analysis of variance) with Tukey's post hoc test with InStat version 3 software (GraphPad Software, Inc., San Diego, CA, USA). Densitometric analyses were performed using the freeware ImageJ by quantifying the band intensity of the protein of interest with respect to the intensity of the relative loading control band (i.e., vinculin). The number of experiments is given in the figure text. Data are shown as the mean \pm standard deviation. For all analyses, a $p$ value $<0.01$ indicated significance.

Supplementary Materials: Supplementary materials can be found at http://www.mdpi.com/1422-0067/21/10/ 3418/s1. Figure S1: The effect of telaprevir on $E R \alpha$ intracellular levels.

Author Contributions: Most of the work was performed by S.B., S.L. performed BrdU incorporation, cell cycle analysis and growth curve analyses. F.A. carried out the experimental design and data analysis and guaranteed funding acquisition. S.B. and F.A. wrote the paper. All authors have read and agreed to the published version of the manuscript.

Funding: The research leading to these results received funding from AIRC under IG 2018-ID. 21325 project P.I. Acconcia Filippo. This study was also supported by grants from Ateneo Roma Tre and Fondo di Finanziamento per le Attività base di Ricerca (FFABR) to FA. The Grant of Excellence Departments, MIUR (ARTICOLO 1, COMMI 314-337 LEGGE 232/2016) to the Department of Science, University Roma TRE is also gratefully acknowledged.

Acknowledgments: The authors also thank Simak Ali, University of London Imperial College, England for the gift of the Y537S-MCF-7 cells.

Conflicts of Interest: The authors declare no conflicts of interest.

\section{References}

1. Ascenzi, P.; Bocedi, A.; Marino, M. Structure-function relationship of estrogen receptor alpha and beta: Impact on human health. Mol. Asp. Med. 2006, 27, 299-402. [CrossRef] [PubMed]

2. Fuentes, N.; Silveyra, P. Estrogen receptor signaling mechanisms. Adv. Protein Chem. Struct. Biol. 2019, 116, 135-170. [CrossRef] [PubMed]

3. Busonero, C.; Leone, S.; Bartoloni, S.; Acconcia, F. Strategies to degrade estrogen receptor alpha in primary and ESR1 mutant-expressing metastatic breast cancer. Mol. Cell. Endocrinol. 2019, 480, 107-121. [CrossRef] [PubMed]

4. Acconcia, F.; Ascenzi, P.; Bocedi, A.; Spisni, E.; Tomasi, V.; Trentalance, A.; Visca, P.; Marino, M. Palmitoylation-dependent estrogen receptor alpha membrane localization: Regulation by 17 beta-estradiol. Mol. Biol. Cell 2005, 16, 231-237. [CrossRef] [PubMed]

5. La Rosa, P.; Pesiri, V.; Leclercq, G.; Marino, M.; Acconcia, F. Palmitoylation Regulates 17beta-Estradiol-Induced Estrogen Receptor-alpha Degradation and Transcriptional Activity. Mol. Endocrinol. 2012, 26, 762-774. [CrossRef] 
6. Pedram, A.; Razandi, M.; Lewis, M.; Hammes, S.; Levin, E.R. Membrane-localized estrogen receptor alpha is required for normal organ development and function. Dev. Cell 2014. [CrossRef]

7. Adlanmerini, M.; Solinhac, R.; Abot, A.; Fabre, A.; Raymond-Letron, I.; Guihot, A.L.; Boudou, F.; Sautier, L.; Vessieres, E.; Kim, S.H.; et al. Mutation of the palmitoylation site of estrogen receptor alpha in vivo reveals tissue-specific roles for membrane versus nuclear actions. Proc. Natl. Acad. Sci. USA 2014, 111, E283-E290. [CrossRef]

8. Acconcia, F.; Marino, M. The Effects of 17beta-estradiol in Cancer are Mediated by Estrogen Receptor Signaling at the Plasma Membrane. Front. Physiol. 2011, 2, 30. [CrossRef]

9. Acconcia, F.; Fiocchetti, M.; Marino, M. Xenoestrogen regulation of ERalpha/ERbeta balance in hormone-associated cancers. Mol. Cell. Endocrinol. 2016. [CrossRef]

10. Leclercq, G.; Lacroix, M.; Laios, I.; Laurent, G. Estrogen receptor alpha: Impact of ligands on intracellular shuttling and turnover rate in breast cancer cells. Curr. Cancer Drug Targets 2006, 6, 39-64. [CrossRef]

11. Totta, P.; Busonero, C.; Leone, S.; Marino, M.; Acconcia, F. Dynamin II is required for 17beta-estradiol signaling and autophagy-based ERalpha degradation. Sci. Rep. 2016, 6, 23727. [CrossRef] [PubMed]

12. Lumachi, F.; Luisetto, G.; Basso, S.M.; Basso, U.; Brunello, A.; Camozzi, V. Endocrine therapy of breast cancer. Curr. Med. Chem. 2011, 18, 513-522. [CrossRef] [PubMed]

13. Busonero, C.; Leone, S.; Acconcia, F. Emetine induces estrogen receptor alpha degradation and prevents 17beta-estradiol-induced breast cancer cell proliferation. Cell. Oncol. 2017. [CrossRef] [PubMed]

14. Busonero, C.; Leone, S.; Klemm, C.; Acconcia, F. A functional drug re-purposing screening identifies carfilzomib as a drug preventing 17beta-estradiol: ERalpha signaling and cell proliferation in breast cancer cells. Mol. Cell. Endocrinol. 2018, 460, 229-237. [CrossRef]

15. Leone, S.; Busonero, C.; Acconcia, F. A high throughput method to study the physiology of E2:ERalpha signaling in breast cancer cells. J. Cell. Physiol. 2018, 233, 3713-3722. [CrossRef]

16. Totta, P.; Gionfra, F.; Busonero, C.; Acconcia, F. Modulation of 17beta-Estradiol Signaling on Cellular Proliferation by Caveolin-2. J. Cell. Physiol. 2015. [CrossRef]

17. Totta, P.; Pesiri, V.; Enari, M.; Marino, M.; Acconcia, F. Clathrin Heavy Chain Interacts With Estrogen Receptor alpha and Modulates 17beta-Estradiol Signaling. Mol. Endocrinol. 2015, 29, 739-755. [CrossRef]

18. Menendez, J.A.; Lupu, R. Fatty acid synthase regulates estrogen receptor-alpha signaling in breast cancer cells. Oncogenesis 2017, 6, e299. [CrossRef]

19. Vethakanraj, H.S.; Sesurajan, B.P.; Padmanaban, V.P.; Jayaprakasam, M.; Murali, S.; Sekar, A.K. Anticancer effect of acid ceramidase inhibitor ceranib-2 in human breast cancer cell lines MCF-7, MDA MB-231 by the activation of SAPK/JNK, p38 MAPK apoptotic pathways, inhibition of the Akt pathway, downregulation of ERalpha. Anti-Cancer Drugs 2018, 29, 50-60. [CrossRef]

20. Busonero, C.; Leone, S.; Bianchi, F.; Acconcia, F. In silico screening for ER $\alpha$ downmodulators identifies thioridazine as an anti-proliferative agent in primary, 4OH-tamoxifen-resistant and Y537S ER $\alpha$-expressing breast cancer cells. Cell. Oncol. 2018. [CrossRef]

21. Gentile, I.; Viola, C.; Borgia, F.; Castaldo, G.; Borgia, G. Telaprevir: A promising protease inhibitor for the treatment of hepatitis C virus infection. Curr. Med. Chem. 2009, 16, 1115-1121. [CrossRef] [PubMed]

22. Bertino, G.; Ardiri, A.; Proiti, M.; Rigano, G.; Frazzetto, E.; Demma, S.; Ruggeri, M.I.; Scuderi, L.; Malaguarnera, G.; Bertino, N.; et al. Chronic hepatitis C: This and the new era of treatment. World J. Hepatol. 2016, 8, 92-106. [CrossRef]

23. Weir, H.M.; Bradbury, R.H.; Lawson, M.; Rabow, A.A.; Buttar, D.; Callis, R.J.; Curwen, J.O.; de Almeida, C.; Ballard, P.; Hulse, M.; et al. AZD9496: An Oral Estrogen Receptor Inhibitor That Blocks the Growth of ER-Positive and ESR1-Mutant Breast Tumors in Preclinical Models. Cancer Res. 2016, 76, 3307-3318. [CrossRef] [PubMed]

24. Joseph, J.D.; Darimont, B.; Zhou, W.; Arrazate, A.; Young, A.; Ingalla, E.; Walter, K.; Blake, R.A.; Nonomiya, J.; Guan, Z.; et al. The selective estrogen receptor downregulator GDC-0810 is efficacious in diverse models of $\mathrm{ER}+$ breast cancer. eLife 2016, 5. [CrossRef]

25. Laios, I.; Journe, F.; Nonclercq, D.; Vidal, D.S.; Toillon, R.A.; Laurent, G.; Leclercq, G. Role of the proteasome in the regulation of estrogen receptor alpha turnover and function in MCF-7 breast carcinoma cells. J. Steroid Biochem. Mol. Biol. 2005, 94, 347-359. [CrossRef] [PubMed] 
26. Pesiri, V.; La Rosa, P.; Stano, P.; Acconcia, F. Identification of an estrogen receptor alpha non-covalent ubiquitin binding surface: Role in 17beta-estradiol-induced transcriptional activity. J. Cell Sci. 2013, 126, 2577-2582. [CrossRef]

27. Metivier, R.; Penot, G.; Hubner, M.R.; Reid, G.; Brand, H.; Kos, M.; Gannon, F. Estrogen receptor-alpha directs ordered, cyclical, and combinatorial recruitment of cofactors on a natural target promoter. Cell 2003, 115, 751-763. [CrossRef]

28. Reid, G.; Hubner, M.R.; Metivier, R.; Brand, H.; Denger, S.; Manu, D.; Beaudouin, J.; Ellenberg, J.; Gannon, F. Cyclic, proteasome-mediated turnover of unliganded and liganded ERalpha on responsive promoters is an integral feature of estrogen signaling. Mol. Cell. 2003, 11, 695-707. [CrossRef]

29. Harrod, A.; Fulton, J.; Nguyen, V.T.M.; Periyasamy, M.; Ramos-Garcia, L.; Lai, C.F.; Metodieva, G.; de Giorgio, A.; Williams, R.L.; Santos, D.B.; et al. Genomic modelling of the ESR1 Y537S mutation for evaluating function and new therapeutic approaches for metastatic breast cancer. Oncogene 2017, 36, 2286-2296. [CrossRef]

30. Cipolletti, M.; Leone, S.; Bartoloni, S.; Busonero, C.; Acconcia, F. Real-time measurement of E2: ERalpha transcriptional activity in living cells. J. Cell. Physiol. 2020. [CrossRef]

31. Scott, S.C.; Lee, S.S.; Abraham, J. Mechanisms of therapeutic CDK4/6 inhibition in breast cancer. Semin. Oncol. 2017, 44, 385-394. [CrossRef] [PubMed]

32. La Rosa, P.; Acconcia, F. Signaling functions of ubiquitin in the 17beta-estradiol (E2): Estrogen receptor (ER) alpha network. J. Steroid Biochem. Mol. Biol. 2011, 127, 223-230. [CrossRef] [PubMed]

33. Totta, P.; Pesiri, V.; Marino, M.; Acconcia, F. Lysosomal Function Is Involved in 17beta-Estradiol-Induced Estrogen Receptor alpha Degradation and Cell Proliferation. PLoS ONE 2014, 9, e94880. [CrossRef] [PubMed]

34. Kiang, T.K.; Wilby, K.J.; Ensom, M.H. Telaprevir: Clinical pharmacokinetics, pharmacodynamics, and drug-drug interactions. Clin. Pharm. 2013, 52, 487-510. [CrossRef]

35. Hurtado, A.; Holmes, K.A.; Ross-Innes, C.S.; Schmidt, D.; Carroll, J.S. FOXA1 is a key determinant of estrogen receptor function and endocrine response. Nat. Genet. 2011, 43, 27-33. [CrossRef]

36. Eeckhoute, J.; Keeton, E.K.; Lupien, M.; Krum, S.A.; Carroll, J.S.; Brown, M. Positive cross-regulatory loop ties GATA-3 to estrogen receptor alpha expression in breast cancer. Cancer Res. 2007, 67, 6477-6483. [CrossRef]

37. Nassa, G.; Salvati, A.; Tarallo, R.; Gigantino, V.; Alexandrova, E.; Memoli, D.; Sellitto, A.; Rizzo, F.; Malanga, D.; Mirante, T.; et al. Inhibition of histone methyltransferase DOT1L silences ERalpha gene and blocks proliferation of antiestrogen-resistant breast cancer cells. Sci. Adv. 2019, 5, eaav5590. [CrossRef]

38. Feng, Q.; Zhang, Z.; Shea, M.J.; Creighton, C.J.; Coarfa, C.; Hilsenbeck, S.G.; Lanz, R.; He, B.; Wang, L.; $\mathrm{Fu}, \mathrm{X}$.; et al. An epigenomic approach to therapy for tamoxifen-resistant breast cancer. Cell Res. 2014, 24, 809-819. [CrossRef]

39. Martin, L.A.; Ribas, R.; Simigdala, N.; Schuster, E.; Pancholi, S.; Tenev, T.; Gellert, P.; Buluwela, L.; Harrod, A.; Thornhill, A.; et al. Discovery of naturally occurring ESR1 mutations in breast cancer cell lines modelling endocrine resistance. Nat. Commun. 2017, 8, 1865. [CrossRef]

40. Fanning, S.W.; Mayne, C.G.; Dharmarajan, V.; Carlson, K.E.; Martin, T.A.; Novick, S.J.; Toy, W.; Green, B.; Panchamukhi, S.; Katzenellenbogen, B.S.; et al. Estrogen receptor alpha somatic mutations Y537S and D538G confer breast cancer endocrine resistance by stabilizing the activating function-2 binding conformation. eLife 2016, 5. [CrossRef]

41. Bahreini, A.; Li, Z.; Wang, P.; Levine, K.M.; Tasdemir, N.; Cao, L.; Weir, H.M.; Puhalla, S.L.; Davidson, N.E.; Stern, A.M.; et al. Mutation site and context dependent effects of ESR1 mutation in genome-edited breast cancer cell models. Breast Cancer Res. BCR 2017, 19, 60. [CrossRef]

42. Williams, M.M.; Cook, R.S. Bcl-2 family proteins in breast development and cancer: Could Mcl-1 targeting overcome therapeutic resistance? Oncotarget 2015, 6, 3519-3530. [CrossRef] [PubMed]

43. Prossnitz, E.R.; Maggiolini, M. Mechanisms of estrogen signaling and gene expression via GPR30. Mol. Cell. Endocrinol. 2009, 308, 32-38. [CrossRef] [PubMed]

44. Molina, L.; Figueroa, C.D.; Bhoola, K.D.; Ehrenfeld, P. GPER-1/GPR30 a novel estrogen receptor sited in the cell membrane: Therapeutic coupling to breast cancer. Expert Opin. Ther. Targets 2017, 21, 755-766. [CrossRef] [PubMed]

45. Fiocchetti, M.; Cipolletti, M.; Ascenzi, P.; Marino, M. Dissecting the $17 \beta$-estradiol pathways necessary for neuroglobin anti-apoptotic activity in breast cancer. J. Cell. Physiol. 2018, 233, 5087-5103. [CrossRef] 
46. Caldon, C.E. Estrogen signaling and the DNA damage response in hormone dependent breast cancers. Front. Oncol. 2014, 4, 106. [CrossRef]

47. Williamson, L.M.; Lees-Miller, S.P. Estrogen receptor alpha-mediated transcription induces cell cycle-dependent DNA double-strand breaks. Carcinogenesis 2011, 32, 279-285. [CrossRef]

48. Bardia, A.; Hurvitz, S. Targeted Therapy for Premenopausal Women with HR(+), HER2(-) Advanced Breast Cancer: Focus on Special Considerations and Latest Advances. Clin. Cancer Res. 2018, 24, 5206-5218. [CrossRef]

49. Meylan, E.; Curran, J.; Hofmann, K.; Moradpour, D.; Binder, M.; Bartenschlager, R.; Tschopp, J. Cardif is an adaptor protein in the RIG-I antiviral pathway and is targeted by hepatitis C virus. Nature 2005, 437, 1167-1172. [CrossRef]

50. Li, K.; Foy, E.; Ferreon, J.C.; Nakamura, M.; Ferreon, A.C.; Ikeda, M.; Ray, S.C.; Gale, M., Jr.; Lemon, S.M. Immune evasion by hepatitis $C$ virus NS3/4A protease-mediated cleavage of the Toll-like receptor 3 adaptor protein TRIF. Proc. Natl. Acad. Sci. USA 2005, 102, 2992-2997. [CrossRef]

51. Li, X.D.; Sun, L.; Seth, R.B.; Pineda, G.; Chen, Z.J. Hepatitis C virus protease NS3/4A cleaves mitochondrial antiviral signaling protein off the mitochondria to evade innate immunity. Proc. Natl. Acad. Sci. USA 2005, 102, 17717-17722. [CrossRef] [PubMed]

52. de Wispelaere, M.; Du, G.; Donovan, K.A.; Zhang, T.; Eleuteri, N.A.; Yuan, J.C.; Kalabathula, J.; Nowak, R.P.; Fischer, E.S.; Gray, N.S.; et al. Small molecule degraders of the hepatitis C virus protease reduce susceptibility to resistance mutations. Nat. Commun. 2019, 10, 3468. [CrossRef] [PubMed]

53. Lan, Q.; Peyvandi, S.; Duffey, N.; Huang, Y.T.; Barras, D.; Held, W.; Richard, F.; Delorenzi, M.; Sotiriou, C.; Desmedt, C.; et al. Type I interferon/IRF7 axis instigates chemotherapy-induced immunological dormancy in breast cancer. Oncogene 2019, 38, 2814-2829. [CrossRef] [PubMed]

54. Bidwell, B.N.; Slaney, C.Y.; Withana, N.P.; Forster, S.; Cao, Y.; Loi, S.; Andrews, D.; Mikeska, T.; Mangan, N.E.; Samarajiwa, S.A.; et al. Silencing of Irf7 pathways in breast cancer cells promotes bone metastasis through immune escape. Nat. Med. 2012, 18, 1224-1231. [CrossRef]

55. Budhwani, M.; Mazzieri, R.; Dolcetti, R. Plasticity of Type I Interferon-Mediated Responses in Cancer Therapy: From Anti-tumor Immunity to Resistance. Front. Oncol. 2018, 8, 322. [CrossRef]

56. Weiss, J.; Becker, J.P.; Haefeli, W.E. Telaprevir is a substrate and moderate inhibitor of P-glycoprotein, a strong inductor of ABCG2, but not an activator of PXR in vitro. Int. J. Antimicrob. Agents 2014, 43, 184-188. [CrossRef]

57. Fujita, Y.; Noguchi, K.; Suzuki, T.; Katayama, K.; Sugimoto, Y. Biochemical interaction of anti-HCV telaprevir with the ABC transporters P-glycoprotein and breast cancer resistance protein. BMC Res. Notes 2013, 6, 445. [CrossRef]

58. Ambudkar, S.V.; Kim, I.W.; Sauna, Z.E. The power of the pump: Mechanisms of action of P-glycoprotein (ABCB1). Eur. J. Pharm. Sci. Off. J. Eur. Fed. Pharm. Sci. 2006, 27, 392-400. [CrossRef]

59. Rotroff, D.M.; Dix, D.J.; Houck, K.A.; Kavlock, R.J.; Knudsen, T.B.; Martin, M.T.; Reif, D.M.; Richard, A.M.; Sipes, N.S.; Abassi, Y.A.; et al. Real-time growth kinetics measuring hormone mimicry for ToxCast chemicals in T-47D human ductal carcinoma cells. Chem. Res. Toxicol. 2013, 26, 1097-1107. [CrossRef]

(C) 2020 by the authors. Licensee MDPI, Basel, Switzerland. This article is an open access article distributed under the terms and conditions of the Creative Commons Attribution (CC BY) license (http://creativecommons.org/licenses/by/4.0/). 